\title{
Semi-industrial production of methane from textile wastewaters
}

\author{
Klaus Opwis ${ }^{*}$, Thomas Mayer-Gall1, Jochen S Gutmann ${ }^{1}$, Christoph Dammer ${ }^{2}$, Tanja Titscher², \\ Anna Nickisch-Hartfiel ${ }^{2}$, Oliver Grün ${ }^{3}$, Christoph Spurk ${ }^{3}$, Christine Schloderer ${ }^{4}$, Axel Köppe ${ }^{4}$, Christian Dörfler $^{5}$ and \\ Herbert Bachus ${ }^{5}$
}

\begin{abstract}
Background: The enzymatic desizing of starch-sized cotton fabrics leads to wastewaters with an extremely high chemical oxygen demand due to its high sugar content. Nowadays, these liquors are still disposed without use, resulting in a questionable ecological pollution and high emission charges for cotton finishing manufacturers.

Methods: In this paper, an innovative technology for the production of energy from textile wastewaters from cotton desizing was developed. Such desizing liquors were fermented by methane-producing microbes to biogas. For this purpose, a semi-industrial plant with a total volume of more than $500 \mathrm{~L}$ was developed and employed over a period of several weeks.

Results: The robust and trouble-free system produces high amounts of biogas accompanied by a significant reduction of the COD of more than $85 \%$. With regard to growing standards and costs for wastewater treatment and disposal, the new process can be an attractive alternative for textile finishing enterprises in wastewater management, combining economic and ecological benefits.

Conclusion: Moreover, the production of biogas from textile wastewaters can help to overcome the global energy gap within the next decades, especially with respect to the huge dimension of cotton pretreatment and, therefore, huge desizing activities worldwide.
\end{abstract}

Keywords: cotton pretreatment, desizing, wastewater, COD, methane, biogas

\section{Background}

In the manufacturing of cotton yarns to textile fabrics, socalled sizing agents are needed in order to protect the warp threads against huge mechanical stress in the weaving process. Apart from synthetic agents, starch is still the most important sizing agent, and more than 1 million tons of starch are used per year worldwide. After weaving, the starch has to be removed from the raw cotton fabric to avoid impairments in the following finishing steps such as scouring, bleaching, and dyeing. Since many decades, the desizing of starch-sized cotton has been conducted by the use of $\alpha$-amylases, which are able to hydrolyze the waterinsoluble starch to water-soluble oligosaccharides under moderate conditions compared to the harsh oxidative

\footnotetext{
* Correspondence: opwis@dtnw.de

${ }^{1}$ Deutsches Textilforschungszentrum Nord-West e.V., Adlerstraße 1, Krefeld, 47798, Germany

Full list of author information is available at the end of the article
}

procedures [1,2]. However, the enzymatic desizing procedure leads to wastewaters with very high sugar content and therefore, an extremely high chemical oxygen demand [COD]. Nowadays, these liquors are still disposed without use, resulting in a questionable ecological pollution and high emission charges for cotton finishing manufacturers.

Despite highly scientific efforts, up to now, no economic strategy for the recycling of these ecological critical wastewaters exists. Several works, for instance, foresee the enzymatic oxidation of these sugars to gluconic acid and hydrogen peroxide using oxidoreductases such as glucose oxidases and peroxidases with the goal to use them in cotton bleaching steps (Figure 1, left) [3-7]. However, because of the high costs of enzymes and the insufficient bleaching grade, these strategies failed. Another approach aims at the transformation of the sugars to valuable cyclodextrins by applying cyclodextrin glycosyl transferases, but this 


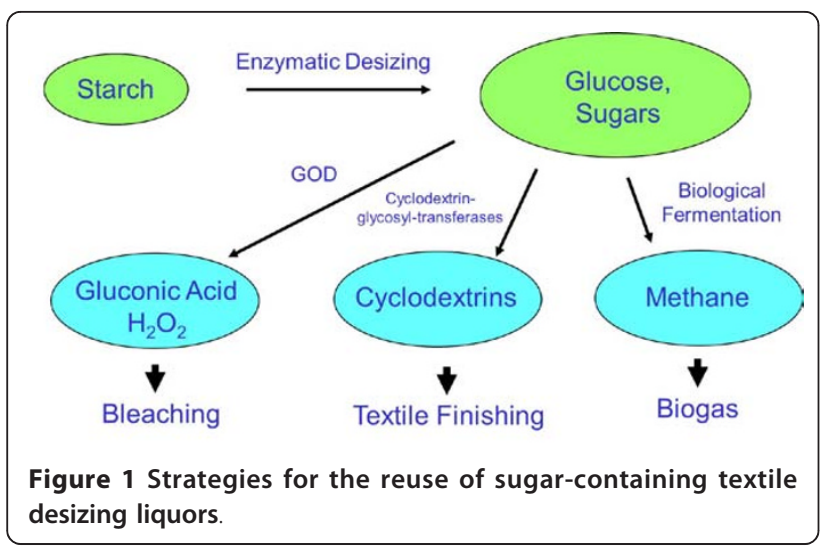

process is still under development and the commercial relevance is not clear at the moment (Figure 1, middle) [8].

In principle, the sugars from desizing are ideal substrates for the biological fermentation to biogas. The biogas process itself is well known, using various microbes for the step-wise transformation of native biomass such as carbohydrates, proteins, and fats to methane. Besides energy from wind, water, and sun power, the generation of energy from organic materials - especially undissolved solid residuals from agriculture - plays the most important role in the production of regenerative energy $[9,10]$. Apart from the obvious wastes from domestic homes and especially economic plants such as corn, wheat, rice, and all kinds of vegetables and fruits, various industry-specific recycling strategies have been developed to generate an added value in the production chain and to minimize pollutions. This includes the biogas generation from wastewaters coming from, e.g., food, chemical, and pharmaceutical industries [11-17]. In the textile industry, and especially here in the cotton manufacturing, various scientific groups are investigating the biogas or bio-ethanol production starting from solid residuals such as willow dusts or fiber wastes with a subsequent enzymatic or chemical hydrolysis of the cellulosic material [18-21].
Here, the pre-hydrolyzed saccharides coming from the enzymatic desizing step in cotton pretreatment are already in the liquefied state and can be applied directly to anaerobic fermentation. In our previous work, we described this process (Figure 1, right), dealing with the biological transformation of such sugar-containing wastewaters from textile desizing liquors to methane-containing biogas [22]. After showing the principle feasibility of the new innovative strategy, here, the change to more industrial relevant continuous reactor conditions and the upscaling is described and completed by an economic and ecological outlook of the overall process.

Especially in these days of climate change, where huge polluting catastrophes such as the oil disaster in the gulf of Mexico (2010) and the nuclear accident in Japan (2011) are querying more and more the energy supply by fossil fuels and nuclear power, alternatives from renewable resources, wind, water, and solar energies, are essential to overcome the energy gap within the next decades. Therefore, the present investigation is another contribution to make this world cleaner and safer.

\section{Methods}

\section{Liquid substrate}

Industrial liquors from enzymatic desizing processes were delivered by Textilveredlung an der Wiese (Loerrach, Germany). Within an industrial washing machine (schematically shown in Figure 2), the desizing liquors were squeezed from the wetted cotton material with a high pressure squeezer. A sample drawing was carried out in the first washing compartment of the industrial washing machine, where the highest carbohydrate concentration was expected. The industrial desizing liquors were directly taken as substrates for the anaerobic biogas generation without any additives. To characterize the initial desizing liquors, various analytical procedures were carried out (see 'Analytics' section).

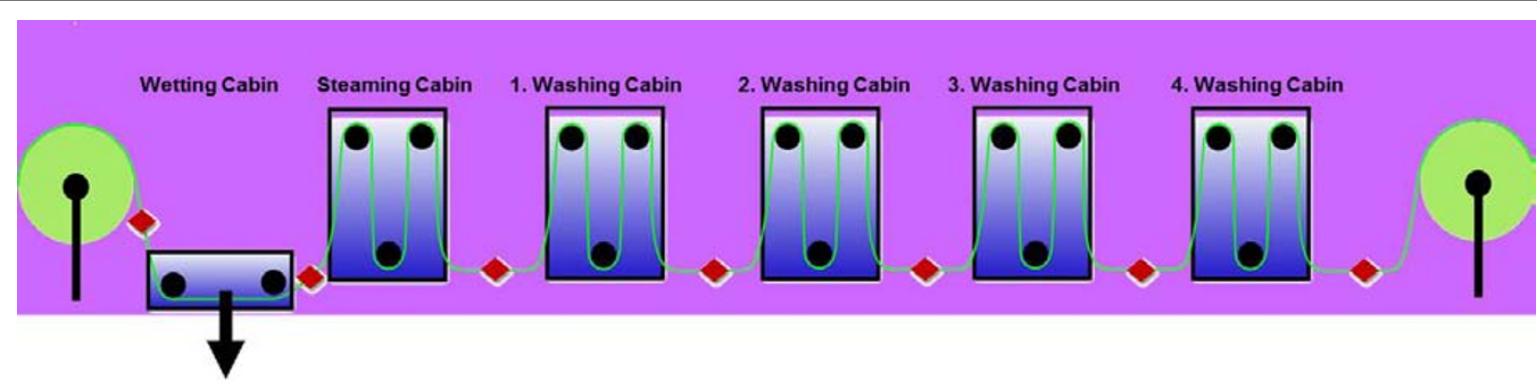

\section{sampling $\rightarrow$ highest COD expected}

Figure 2 A schematic of the industrial washing machine used and place of liquor sampling. 


\section{Lab-scale reactor}

First, the continuous anaerobic fermentation of the desizing liquors was carried out in a lab-scale biogas reactor with biomass recirculation at $38^{\circ} \mathrm{C}$ schematically shown in Figure 3 . The sugar-containing medium was supplied in an upstream mixing chamber, where the $\mathrm{pH}$ value was adjusted to 7.2. Adequate microbes for the biological transformation were taken from an agricultural biogas plant (Wassenberg, Germany). The total volume of the system accounts $4.8 \mathrm{~L}$. Within this reactor, the methane content of the produced biogas was determined by an infrared BCP-CH4 (BlueSens GBR, Herten, Germany).

\section{Semi-industrial biogas plant}

By upscaling the reactor to a total volume of $550 \mathrm{~L}$ (main fermenter $430 \mathrm{~L}$ ) the continuous semi-industrial fermentation was conducted in a system schematically illustrated in Figure 4. The system is able to measure several parameters such as temperature, pressure, $\mathrm{pH}$ value, tank filling height, volume flow, generated gas amount, and chemical gas composition online and simultaneously.

\section{Analytics}

The COD, the total organic carbon [TOC], and the total nitrogen of the desizing liquors were measured using the testing kits HT-COD LCK 014, TOC LCK 387, and LatoN LCK 338 (HACH LANGE GMBH, Duesseldorf, Germany), respectively. The element contents of the initial desizing liquor were determined according to DIN EN 13346. About $100 \mathrm{~mL}$ of desizing liquor was liberated from water by heating and followed by drying for $6 \mathrm{~h}$ at $80^{\circ} \mathrm{C}$. About $300 \mathrm{mg}$ of the waterless residue was treated with $6.0 \mathrm{~mL}$ of concentrated $\mathrm{HNO}_{3}(65 \%)$ and $2.0 \mathrm{~mL}$ of concentrated $\mathrm{HCl}(37 \%)$ digested in a microwave digester (MARSXpress, CEM, Kamp-Lintfort, Germany) at $180^{\circ} \mathrm{C}$. The completely digested samples as a clear solution were transferred to a $25-\mathrm{mL}$ volumetric

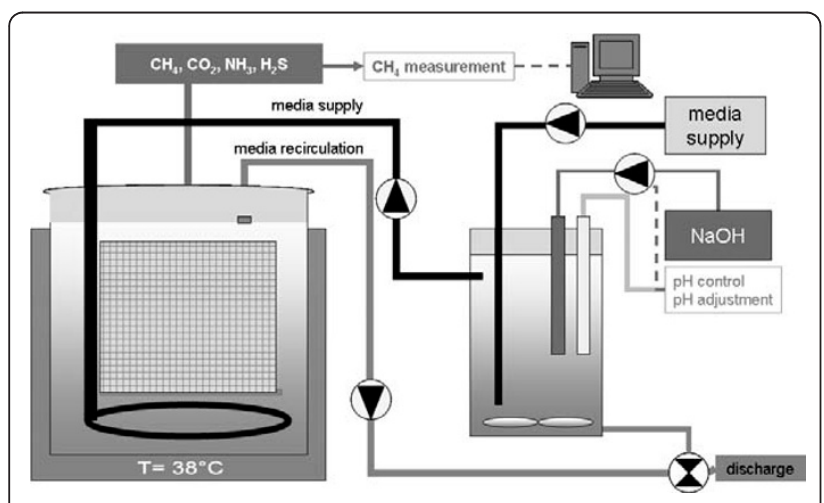

Figure 3 A schematic of the lab-scale biogas reactor with biomass recirculation and $\mathrm{pH}$ control.

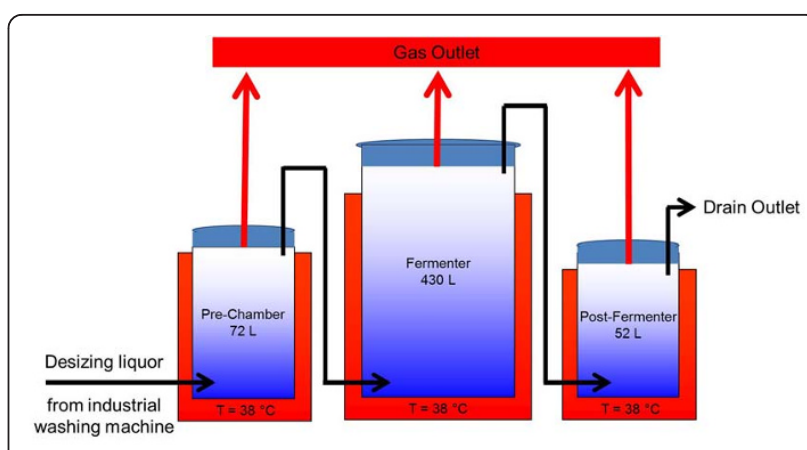

Figure $4 \mathrm{~A}$ schematic of the semi-industrial biogas plant.

flask and subsequently diluted with distilled water. The samples thus prepared were analyzed using an inductively coupled plasma optical emission spectrometer [ICP/OES] (720-ES, Varian Medical Systems GmbH, Darmstadt, Germany) to determine the element concentrations.

\section{Toxicological studies (TTC test)}

The dehydrogenase activities of living microorganisms reduce the redox indicators such as the colorless triphenyl tetrazolium chloride [TTC] to red formazan (absorption maximum at $480 \mathrm{~nm}$ ). Therefore, $4.5 \mathrm{~mL}$ of desizing liquor (i.e., $4.5 \mathrm{~mL}$ of $2 \%$ aqueous glucose solution as a blank test) was inoculated with $4.5 \mathrm{~mL}$ of bacterial population from the methane reactor and $1.0 \mathrm{~mL}$ TTC $(51 \mathrm{mg} / \mathrm{mL})$. After an incubation time of 2, 4, and $24 \mathrm{~h}$, the color generation was measured. The red color indicates living cells, i.e., a nontoxic behavior of the medium.

\section{Results and discussion}

The chemical and biological characterizations of the squeezed desizing liquors from the typical enzymatic desizing process in cotton pretreatment evidence the ideal properties for a biological anaerobic fermentation. The high sugar load coming from starch leads to an average COD of $40 \mathrm{~g} / \mathrm{L}$ and a TOC of $13.2 \mathrm{~g} / \mathrm{L}$. Moreover, the liquors contain $0.3 \mathrm{~g} / \mathrm{L}$ nitrogen and $65 \mathrm{mg} / \mathrm{L}$ phosphorus which assist the growth of the biogas-forming microbes. The $\mathrm{pH}$ value is in the range of moderate 6.0, and no toxic metals were found when conducting the ICP/OES study. In addition, the absence of toxic components has been proven by toxicological studies using the TTC test. Within this test, the dehydrogenase activity of living microorganisms reduces the colorless TTC to red formazan (Figure 5).

Figure 6 presents the results of the TTC test. The red color of the generated formazan can clearly be seen, indicating living cells in the presence of the textile desizing liquors. No hint was observed that the desizing 


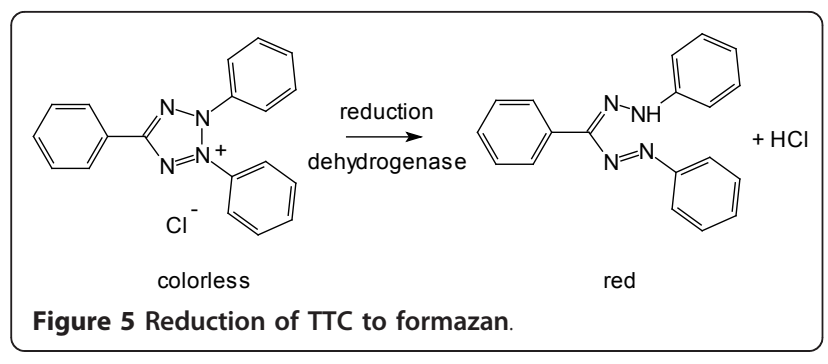

liquors inhibit or even kill the bacteria. In total, the present properties allow a direct use of the liquors without any subsequent treatment or accumulation - apart from a slight raise of the $\mathrm{pH}$ value to 7.2 using caustic soda to reach optimal fermentation conditions.

The studies on biogas production have been started with a static gas emission experiment carried out with the desizing liquor in the presence of the seeding sludge from the agricultural biogas plant (Wassenberg, Germany). Figure 7 shows the corrected time-dependent gas emission of the desizing liquor over a period of $524 \mathrm{~h}$.

The outgassing starts rapidly with a strong generation of biogas within the first $120 \mathrm{~h}$, where approximately two thirds of the total biogas amount was accumulated. Afterwards, the curve flattened significantly, and after 360 to $400 \mathrm{~h}$ ( $c a .15$ to 16 days), the biogas generation was finished to the greatest possible extent. The experiment was interrupted after $524 \mathrm{~h}$. At this moment, 27 $\mathrm{m}^{3}$ of biogas was generated per cubic meter of textile desizing liquor. The methane content within the produced biogas amounted to $51 \%$.

Based on these results, the feed supply within the labscale reactor was adjusted to $0.22 \mathrm{~mL}$ of the desizing liquor per minute, which is corresponding to an absolute dwell time of again approximately 15 days (reactor

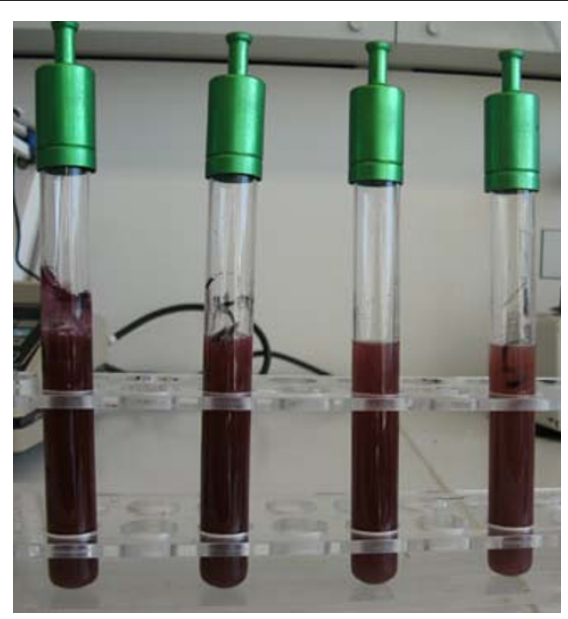

Figure 6 TTC test with the used microbes in the presence of the industrial desizing liquor.

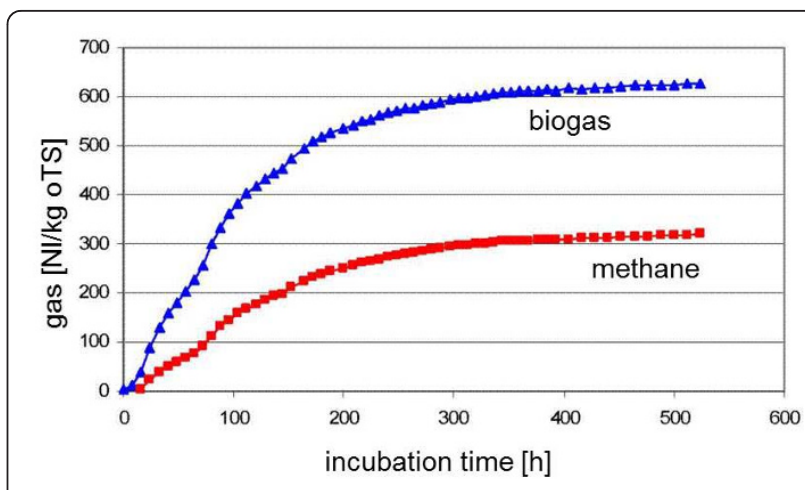

Figure 7 Time-dependent gas emission under static fermentation conditions. The gas volumes were corrected by the gas generation of the seeding sludge.

volume $=4.8 \mathrm{~L})$. Under these continuous fermentation conditions, an effective biogas production was observed with a COD reduction in the range of $50 \%$ to $75 \%$ over a period of 72 days (see Figure 8, lab-scale reactor).

The hydraulic design of the semi-industrial plant was aligned with the results from the lab-scale reactor and the static gas emission experiments. The measured dwell time (15 to 16 days) was supplemented by a conservative overhead of $50 \%$, leading to a maximal expected dwell time in the new reactor of 24 days. The main fermenter has an absolute volume of $430 \mathrm{~L}$, and therefore, a needed input of $18 \mathrm{~L}$ of desizing liquor per day resulted in a calculated biogas production of $486 \mathrm{~L} /$ day.

After implementing the continuous fermentation process, a constant biogas production was observed. Table 1

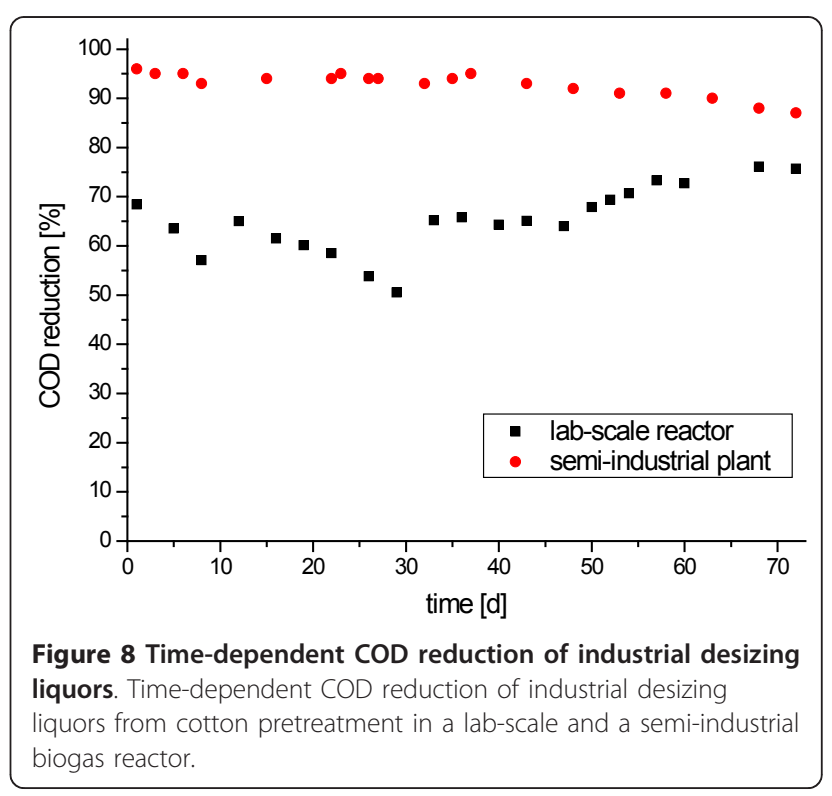


Table 1 Chemical composition of biogas generated in the semi-industrial fermentation plant

\begin{tabular}{llcc}
\hline Parameter & Method of determination & Result & Unit \\
\hline Methane & According to EN ISO 69746 & 58.5 & vol.\% \\
Carbon dioxide & According to EN ISO 69746 & 37.6 & vol.\% \\
Nitrogen & According to EN ISO 69746 & 3.33 & vol.\% \\
Oxygen & According to EN ISO 69746 & 0.34 & vol.\% \\
Hydrogen & According to EN ISO 69746 & 60 & ppm \\
Hydrogen sulfide & According to DIN 518558 & 2,597 & $\mathrm{ppm}$ \\
\hline
\end{tabular}

shows the average chemical composition of the biogas with a methane content of almost $60 \mathrm{vol} . \%$.

Moreover, a high reduction of the COD within the drain outlet was detected. Figure 8 demonstrates a relative decrease of COD over the regarded period of 72 days. Compared to the lab-scale reactor, the semi-industrial plant exhibits a further improvement of the degradation performance to average levels of more than $85 \%$ due to the higher dwell time of 24 days (instead of 15 days within the lab-scale reactor).

\section{Conclusions}

To implement an economic and ecological sustainable textile finishing of cotton, innovative technologies are becoming more and more important which enable the recycling process of water, textile auxiliaries, or energy. The creation of such in-house cycles leads to an increased cost-effectiveness and a minimization of emissions.

In this context, the aim of our work was the development of an easy and inexpensive strategy for the minimization of high COD loads in textile wastewaters occurring in the enzymatic desizing of cotton fabrics accompanied by the generation of energy. This has been succeeded by the biological transformation of the sugarcontaining wastewaters to biogas with methane-producing microbes.

After demonstrating the general feasibility of the envisaged process on a lab-scale, a semi-industrial plant was developed and employed over a period of 72 days under continuous and therefore, praxis-relevant conditions. The results show that also the upscaled system produces huge amounts of biogas with a high methane content of almost 60 vol.\% in a robust and trouble-free way. The COD reduction in the wastewater of more than $85 \%$, on one hand, and the production of a valuable energy source, on the other, yield two economic advantages.

Thus, an innovative technology for the production of energy from textile wastewaters was developed. With regard to growing standards and costs for wastewater treatment and disposal, the new process can be an attractive alternative for textile finishing enterprises and is accompanied with economic and ecological benefits.
Table 2 Target values and hydraulic dimensions of a pilot plant for biogas production from textile wastewaters

\begin{tabular}{lc}
\hline Parameter & Value \\
\hline Dwell time target value & 20 days \\
Wastewater amount & $7,200 \mathrm{~L} /$ working day \\
Average wastewater amount & $4,700 \mathrm{~L} /$ day \\
Gas production & $27 \mathrm{~m}^{3}$ gas $/ \mathrm{m}^{3}$ wastewater \\
Gas production & $5.3 \mathrm{~m}^{3} / \mathrm{h}$ \\
Volume of the collection container & $25 \mathrm{~m}^{3}$ \\
Volume of the pre-chamber & $10 \mathrm{~m}^{3}$ \\
Volume of the main fermenter & $100 \mathrm{~m}^{3}$ \\
Volume of the post-fermenter & $50 \mathrm{~m}^{3}$ \\
Volume of the gas tank & $300 \mathrm{~m}^{3}$ \\
\hline
\end{tabular}

Moreover, the production of biogas from textile wastewaters is another brick to overcome the global energy gap within the next decades, especially with respect to the huge dimension of cotton pretreatment (global annual output 25 million tons) and, therefore, huge desizing activities worldwide.

The next step should be another upscale from the semi-industrial to a pilot plant. Regarding the size of the industrial washing machine and an estimated annual cotton production of 2,000 tons, we expect a daily average wastewater amount of approximately $4,700 \mathrm{~L}$. With respect to an envisaged target value of a 20 -day dwell time, the main fermenter of the new pilot plant should have a volume of nearly $100 \mathrm{~m}^{3}$. The hydraulic dimensions are summarized in Table 2. The economic benefits of an installation of such plants strongly depend on the national and local conditions and costs for wastewater disposal and energy. An amortization calculation should be carried out individually.

\section{Acknowledgements}

The authors would like to thank the Deutsche Bundesstiftung Umwelt e.V. for the financial support of the project DBU Az 26589 'Entwicklung einer Verfahrenstechnik zur Generierung von Methan aus Stärkeschlichte in der textilen Vorbehandlung von Baumwolle'.

\section{Author details}

${ }^{1}$ Deutsches Textilforschungszentrum Nord-West e.V., Adlerstraße 1, Krefeld, 47798, Germany ${ }^{2}$ Hochschule Niederrhein, Reinarzstraße 49, Krefeld, 47805, Germany ${ }^{3} \mathrm{OeKOBiT} \mathrm{GmbH}$, Jean-Monnet-Straße 12, Foehren, 54343, Germany ${ }^{4}$ Textilveredlung an der Wiese, Schopfheimer Straße 27, Loerrach, 79541, Germany ${ }^{5} \mathrm{CHT}$ R. Beitlich GmbH, Bismarckstraße 102, Tuebingen, 72072, Germany

\section{Authors' contributions}

$\mathrm{CD}, \mathrm{T}$, and $\mathrm{AN}-\mathrm{H}$ carried out the lab-scale bioreactor experiments and the toxicological studies. CS and AK provided the industrial desizing liquors and all relevant data for the upscale. OG and CS constructed the semi-industrial biogas plant and carried out all upscaled experiments. $C D$ and $H B$ performed the analytical section. $\mathrm{KO}, \mathrm{TM}-\mathrm{G}$, and JG conceived the study and participated in its design and coordination. All authors read and approved the final manuscript. 


\section{Competing interests}

The authors declare that they have no competing interests.

Received: 11 October 2011 Accepted: 17 January 2012

Published: 17 January 2012

\section{References}

1. Marcher D, Hagen HA, Castelli S (1993) Entschlichten mit enzymen. ITB Veredlung 39(3):20-32

2. Cavaco-Paulo A (1998) Processing textile fibers with enzymes: an overview In: Eriksson KEL, Cavaco-Paulo A (ed) Enzyme applications in fiber processing, ACS symposium series. American Chemical Society, Washington, DC

3. Opwis K, Knittel D, Kele A, Schollmeyer E (1999) Enzymatic recycling of starch containing desizing liquors. Starch 51(10):348-353. doi:10.1002/(SICl) 1521-379X(199910)51:103.0.CO;2-K.

4. Buschle-Diller G, Yang XD (2001) Enzymatic bleaching of cotton fabric with glucose oxidase. Textile Res J 71(5):388-394. doi:10.1177/ 004051750107100504.

5. Shin Y, Hwang S, Ahn I (2004) Enzymatic bleaching of desized cotton fabrics with hydrogen peroxide produced by glucose oxidase. J Ind Eng Chem 10(4):577-581

6. Saravanan D, Ramachandran $T$ (2010) Bleaching of cotton fabrics using hydrogen peroxide produced by glucose oxidase. Indian J Fibre \& Textile Res 35:281-283

7. Opwis K, Knittel D, Schollmeyer E, Hoferichter P, Cordes A (2008) Simultaneous application of glucose oxidases and peroxidases in bleaching processes. Eng Life Sci 8:175-178. doi:10.1002/elsc.200720237.

8. Opwis K Enzymatic generation of cyclodextrins from textile desizing liquors, unpublished data.

9. Deublein D, Steinhauser A (2008) Biogas from waste and renewable resources: an introduction. Wiley, Weinheim

10. Pimentel D (2008) Biofuels, solar and wind as renewable energy systems: benefits and risks. Springer, Berlin, 1

11. Sakar S, Yetilmezsoy K, Kocak E (2009) Anaerobic digestion technology in poultry and livestock waste treatment-a literature review. Waste Manag Res 27(1):3-18. doi:10.1177/0734242X07079060.

12. Leitão RC, Araújo AM, Freitas-Neto MA, Rosa MF, Santaella ST (2009) Anaerobic treatment of coconut husk liquor for biogas production. Water Sci Technol 59(9):1841-1846. doi:10.2166/wst.2009.187.

13. Fezzani B, Ben Cheikh R (2008) Optimisation of the mesophilic anaerobic co-digestion of olive mill wastewater with olive mill solid waste in a batch digester. Desalination 228(1-3):159-167. doi:10.1016/j.desal.2007.09.007.

14. Kumar A, Yadav AK, Sreekrishnan TR, Satya S, Kaushik CP (2008) Treatment of low strength industrial cluster wastewater by anaerobic hybrid reactor. Bioresource Technol 99(8):3123-3129. doi:10.1016/j.biortech.2007.05.056.

15. Shen DS, He R, Liu XW, Long Y (2006) Effect of pentachlorophenol and chemical oxygen demand mass concentrations in influent on operational behaviors of upflow anaerobic sludge blanket (UASB) reactor. J Hazard Mater 136(3):645-653. doi:10.1016/j.jhazmat.2005.12.050.

16. Oktem YA, Ince O, Sallis P, Donnelly T, Ince BK (2008) Anaerobic treatment of a chemical synthesis-based pharmaceutical wastewater in a hybrid upflow anaerobic sludge blanket reactor. Bioresource Technol 99(5):1089-1096. doi:10.1016/j.biortech.2007.02.036.

17. Tawfik A, El-Gohary F, Temmink H (2010) Treatment of domestic wastewate in an up-flow anaerobic sludge blanket reactor followed by moving bed biofilm reactor. Bioprocess Biosyst Eng 33(2):267-276. doi:10.1007/s00449009-0321-1.

18. Balasubramanya RH, Khandeparkar VG, Sundaram V (1988) Large-scale digestion of willow-dust in batch digesters. Biological Wastes 25(1):25-32. doi:10.1016/0269-7483(88)90124-3.

19. Sundar Raj C, Arul S, Sendilvelan S, Saravanan CG (2009) Biogas from textile cotton waste-an alternate fuel for diesel engines. The Open Waste Manage J 2:1-5. doi:10.2174/1876400200902010001.

20. Rajesh ARR, Rajesh EM, Rajendran R, Jeyachandran S (2008) Production of bio-ethanol from cellulosic cotton waste through microbial extracellular enzymatic hydrolysis and fermentation. EJEAFChe 7(6):2984-2992

21. Chandrashekhar B, Mishra MS, Sharma K, Dubey S (2011) Bio-ethanol production from textile cotton waste via dilute acid hydrolysis and fermentation by Saccharomyces cerevisiae. J Ecobiotechnol 3(4):6-9
22. Opwis K, Mayer-Gall T, Schollmeyer E, Dammer C, Titscher T, NickischHartfiel A, Grün O, Spurk C, Schloderer C, Köppe A, Dörfler C, Bachus H (2010) Generation of methane from textile desizing liquors. Eng Life Sci 10(4):293-296. doi:10.1002/elsc.200900082.

doi:10.1186/2192-0567-2-1

Cite this article as: Opwis et al: Semi-industrial production of methane from textile wastewaters. Energy, Sustainability and Society 2012 2:1.

\section{Submit your manuscript to a SpringerOpen ${ }^{\mathcal{O}}$ journal and benefit from:}

- Convenient online submission

- Rigorous peer review

- Immediate publication on acceptance

- Open access: articles freely available online

- High visibility within the field

- Retaining the copyright to your article

Submit your next manuscript at $\gg$ springeropen.com 